sure this book will be attacked elsewhere as unbalanced. Bear this in mind when you read about Mike Russell's superb scenario for the chemiosmotic properties of the earliest cells, established by geothermal convection. Consider it, too, when reading of "the hydrogen hypothesis for the first eukaryoten from Bill Martin and Miklos Müller. Believe me, people get angry at the idea of the primordial eukaryote being a methane-producer in partnership with a hydrogen-excreting anaerobe that was ancestral to both the mitochondrion and the obscure hydrogenosome. Perhaps the hydrogen hypothesis' is an affront to eukaryotic dignity. Personally, I think it is a liberating idea, and one that will stand the test of time.

The book was written for anyone interested in some of the most profound questions of twenty- first-century science. The central proposals of Power, Sex, Suicide are clearly and forcefully propounded, are serious, have far-reaching consequences - and may even be correct. After all, not so long ago, the chemiosmotic and endosymbiont hypotheses were championed only by those thought to be mad, bad and dangerous to know. Now we read that " the dynamics of the respiratory chain are a force that has shaped the whole trajectory of life. This is a new take on why we are here. Perhaps all genes are 'housekeeping' genes, and vectorial electrons and protons were the authors of evolution — and are still its movers and shakers. Perceptions change. Do, please, read this book. John F. Allen is in the School of Biological and Chemical Sciences, Queen Mary, University of London, Mile End Road, London E1 4NS, UK.

\title{
THEATRE
}

\section{Two exiles}

\section{Einstein's Gift}

by Vern Thiessen, directed by Ron Russell Acorn Theatre, New York, until 6 November 2005

\section{Alan Packer}

If a writer wants to dramatize chemist Fritz Haber's remarkable and agonizing story, there is one sure-fire way to attract a general audience: bring Albert Einstein on stage as the narrator and build your work around the friendship between the two men. This is savvy marketing, and has the advantage of being true to life, as Einstein and Haber were indeed friends and colleagues. The tension between their two personalities is the driving force in Vern Thiessen's prize-winning play, Einstein's Gift, which has just received its US premiere in an absorbing and well-acted production.

It doesn't take much artistic licence to generate an air of tragedy around the facts of Haber's life. Born in 1868 to a Jewish family in the Prussian city of Breslau, he was baptized at the age of 24 . A bulldog of a man, he held, in dangerous combination, an uncritically patriotic view of Germany and a devotion to science as a means to serving it. His major scientific achievement - the Haber-Bosch process for nitrogen fixation, for which he won a Nobel prize - was immense, allowing fertilizers to yield crops that now feed billions of people.

Hoping to hasten the end of the First World War, Haber pioneered the development of chlorine gas as a battlefield weapon, and oversaw its use near the town of Ypres in Belgium. This event, with its obvious implications for warfare during the rest of the twentieth century, had personal consequences as well. It was quite possibly the trigger for his wife Clara's suicide. After the rise of the Nazi party in the 1930 s, Haber, being Jewish, was cast aside by the country to which he had devoted his life. Exiled to Switzerland, depressed and in failing health, he died in a Basel hotel room in 1934.
As Daniel Charles makes clear in Between Genius and Genocide, his fine new biography, which will be reviewed shortly in Nature, Haber's ambition had a somewhat desperate quality to it. Thiessen captures this aspect of Haber's character from the very beginning, with a scene introducing Haber's relationship with fellow exile Einstein. Haber, convincingly portrayed by Aasif Mandvi, has political connections, and revels in the upper hand he holds over his less worldly counterpart, who cares little for the approval of the nation of his birth, and for whom the life of the mind is its own reward.

Haber's courtship of Clara, the philosophical tug-of-war that constitutes his relationship with Einstein, the moment of insight in his work on the production of ammonia, and the horrifying scene at Ypres are all written and staged with eloquence and flair. A climactic scene, in which Haber resigns his post rather than fire scores of Jewish scientists on his staff, is gripping. Thiessen is also aided by John McDermott's set, which, with its period chalkboards and central spiral staircase, lends an air of authenticity throughout.

Yet it must be said that a certain heavyhandedness hovers over several moments in the play. In their final meeting, Einstein's gift to the dying Haber is a tallit (a Jewish prayer shawl). Symbolically this brings the play full circle, but there is no evidence that Haber's lifelong distance from his religion caused him more pain than did his exile from Germany. The play also begins and ends with a simulated nuclear detonation. This is less subtle than it needs to be. After the final flash, Einstein wanders across the stage in anguish, wondering aloud if it is possible to go back in time. "Am I to censor all of my thoughts?" he wonders. That's an excellent and necessary question - a gift in itself. But its relevance to Haber, who was an active participant in the creation of the militaryindustrial complex, is not at all clear.

Despite these discordant notes, Einstein's Gift brings Haber's unhappy story powerfully to life.

Alan Packer is senior editor at Nature Genetics.

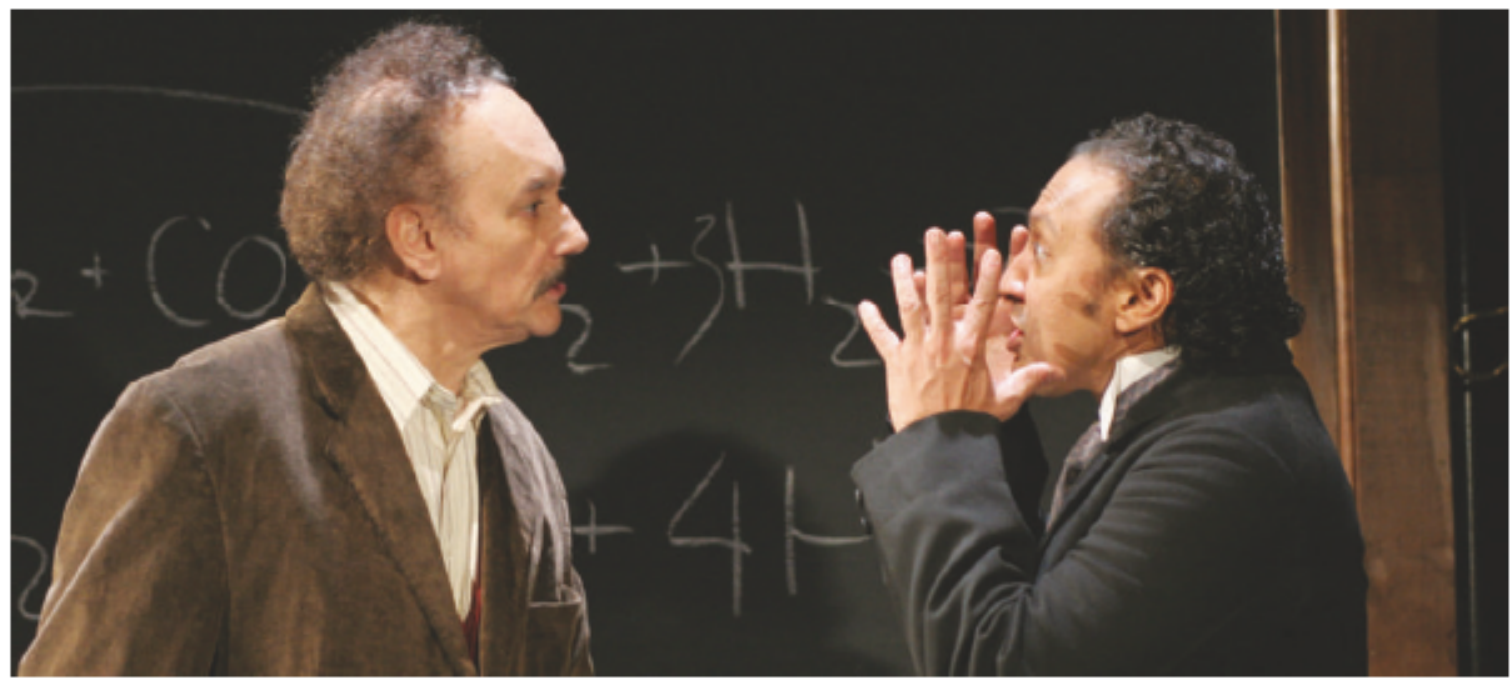

Enstein's Gift explores the relationship between Einstein (Shawn Elliott, left) and Fritz Haber (Aasif Mandvi). 